\title{
Scanning laser polarimetry in glaucomatous and nonglaucomatous Brazilian subjects
}

\author{
Polarimetria de varredura a laser em grupos de brasileirosglaucomatosos e não \\ glaucomatosos
}

\author{
Christiane Rolim de Moura ${ }^{1}$ \\ Paulo Augusto de Arruda Mello ${ }^{2}$ \\ João Antônio Prata Júnior ${ }^{3}$
}

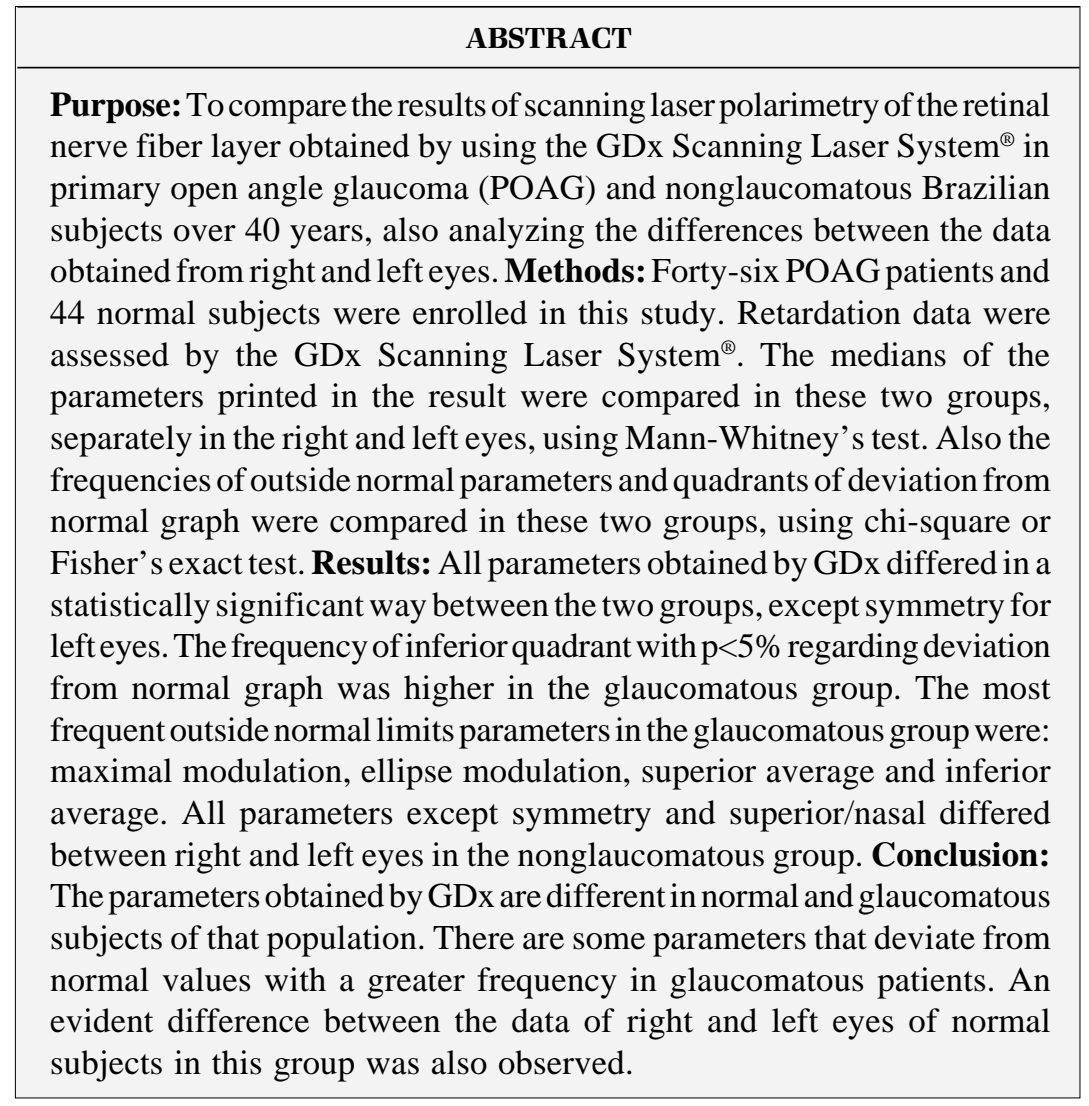

Keywords: Glaucoma; Nerve fibers; Retina/pathology; Ophthalmological diagnostic technics; Perimetry

\section{INTRODUCTION}

Retinal nerve fiber layer (RNLF) analysis has been investigated for early glaucoma diagnosis ${ }^{(1)}$. Some studies suggest that RNFL loss precedes visual field defects by years ${ }^{(2-3)}$ and showed that RNFL defects could be detected in fundus photography five to ten years before visual field abnormalities ${ }^{(3)}$. However fundus photography used for RNFL analysis has some technical limitations such as subjectivity of the examiner and difficulties caused by medium opacities ${ }^{(4)}$.

In this regard some devices have been developed in order to detect and quantify early RNFL loss ${ }^{(5)}$. One of them is based on RNFL birefringence. This technique uses a polarized light with confocal laser technology that 
passes through the nerve fiber layer (retardation) and is called polarimetry ${ }^{(5)}$. This retardation has been correlated with RNFL thickness in histopathologic studies ${ }^{(6)}$.

The GDx Scanning Laser System ${ }^{\circledR}$, Laser Technologies, San Diego, CA, USA is a scanning laser polarimeter that comprises a software, which is based on data obtained in previous studies. It provides parameters which are indicated as normal, borderline or outside normal, when the software compares the database with the data obtained from a suspect patient ${ }^{(7)}$. The actual value of the parameters provided by this software in detecting glaucoma and whether the results are similar in different populations are questions still under investigation.

Weinreb et al., in1998, observed that by adding outside normal parameters, the sensitivity and specificity of the glaucoma diagnosis test are increased, and the most important parameters in a study were ellipse modulation, average thickness and ellipse average ${ }^{(8)}$.

The aim of this study was to analyze the results obtained by the software that comprises the GDx Scanning Laser System ${ }^{\circledR}$, in a group of primary open angle glaucoma patients and nonglaucomatous subjects of a Brazilian population over 40 years, and also to compare the results obtained on right and left eyes.

\section{METHODS}

The study protocol was approved by the Ethics Committee of the Hospital São Paulo and an informed consent was obtained from all participants after the nature of the study had been explained (\#181/98).

\section{Nonglaucomatous subjects}

Forty-four volunteers were enrolled in this study. Inclusion criteria were: age of 40 years or over, no history of eye disease, except refractive error (eyes with spherical equivalent exceeding +6.00 or $-6.00 \mathrm{D}$ were excluded ${ }^{(9-10)}$, intraocular pressure (IOP) of $20 \mathrm{mmHg}$ or less on three different occasions, no prior eye surgery, open angle, no abnormalities on biomicroscopy and dilated fundus examination, cup to disc ratio of 0.4 or less and normal visual fields.

The visual field was tested with a Humphrey ${ }^{\circledR}$ Field Analyzer (HFA), Zeiss Humphrey System, Dublin, CA, USA using a full-threshold 24-2 examination, and was considered normal when it included acceptable reliability, GHT and CPSD within normal limits and not more than two contiguous depressed points in the pattern deviation graph $(\mathrm{p}<5 \%)$.

\section{Glaucomatous patients}

Forty-six primary open angle glaucoma patients were recruited from the Glaucoma Section of the Department of Ophthalmology of the Universidade Federal de São Paulo. Inclusion criteria were: age of 40 years or over, IOP greater than $20 \mathrm{mmHg}$, cup to disc ratio 0.5 or more, no prior eye surgery, open angle, no other abnomalities at biomicroscopy nor dilated fundus examination and abnormal visual field (acceptable reliability, three or more depressed contiguous nonperipheral points in the pattern deviation graph $(\mathrm{p}<5 \%)$, GHT outside normal limits and CPSD with $\mathrm{p}<0.5 \%$ ).

There was no statistically significant difference between the mean age of normal and glaucomatous subjects. Demographic data are summarized in table 1 . Table 2 shows that there was a statistically significant difference between visual field parameters and cup/disc ratio of the two groups.

Thirty-four right eyes and 32 left eyes from the glaucomatous group met the inclusion criteria, while 42 right eyes and

\begin{tabular}{|lcc|}
\hline \multicolumn{3}{c}{ Table 1. Patient demographic data } \\
Age (years) & Glaucomatous & Nonglaucomatous \\
( \pm SD; range) & 61 & 59 \\
Sex & $( \pm 11,6 ; 41$ to 90$)$ & $( \pm 12,1 ; 40$ to 87$)$ \\
& $27(59 \%) \mathrm{F}$ & $36(82 \%) \mathrm{F}$ \\
Race & $19(41 \%) \mathrm{M}$ & $8(18 \%) \mathrm{M}$ \\
& $19(41 \%) \mathrm{W}$ & $29(66 \%) \mathrm{W}$ \\
& $24(52 \%) \mathrm{B}$ & $15(34 \%) \mathrm{B}$ \\
F= female; $\mathrm{M}=$ male; $\mathrm{W}=$ white; $\mathrm{B}=$ black; $\mathrm{Y}=$ Asian & $0 \mathrm{Y}$ \\
\hline
\end{tabular}

\begin{tabular}{|c|c|c|c|c|}
\hline & \multicolumn{2}{|c|}{ Glaucomatous } & \multicolumn{2}{|c|}{ Nonglaucomatous } \\
\hline & OD & OS & OD & OS \\
\hline $\mathrm{MD}(\mathrm{dB})$ & -12.10 & -13.00 & -2.60 & -3.00 \\
\hline$( \pm \mathrm{SD})$ & $( \pm 8.50)^{*}$ & $( \pm 8.20)^{*}$ & $( \pm 2.40)^{*}$ & $( \pm 2.30)^{*}$ \\
\hline CPDS & 5.80 & 6.30 & 1.00 & 1.40 \\
\hline$( \pm S D)$ & $( \pm 3.20)^{*}$ & $( \pm 3.00)^{*}$ & $( \pm 0.70)^{*}$ & $( \pm 1.10)^{*}$ \\
\hline \multicolumn{5}{|l|}{ Cup-to-Disc Ratio: Vertical } \\
\hline $0.1-0.4$ & $0(0)^{*}$ & $0(0)^{*}$ & $39(93 \%)^{*}$ & $37(95 \%)^{*}$ \\
\hline $0.5-0.7$ & $13(36 \%)^{*}$ & $13(38 \%)^{*}$ & $3(7 \%)^{*}$ & $2(5 \%)^{*}$ \\
\hline $0.8-1.0$ & $23(64 \%)^{*}$ & $21(62 \%)^{*}$ & $0^{*}$ & $0^{*}$ \\
\hline Total & $36(100 \%)$ & $34(100 \%)$ & $42(100 \%)$ & $39(100 \%)$ \\
\hline Mean Cup-to-Disc: Vertical ( \pm SD) & $0.79( \pm 0.14)^{*}$ & $0.78( \pm 0.14)^{*}$ & $0.31( \pm 0.12)^{*}$ & $0.30( \pm 0.11)^{*}$ \\
\hline
\end{tabular}


39 left eyes from nonglaucomatous group were included. The more important eye exclusion reasons were: presence of absolute glaucoma or phthisis, cataracts and pseudophakia. These reasons are listed in Table 3 for the glaucomatous and nonglaucomatous groups.

\section{Nerve fiber layer data}

The retardation data were obtained by the GDx Scanning Laser System ${ }^{\circledR}$, Laser Diagnostic Technologies, Inc., San Diego, CA, USA in a room with constant illumination, before pupil dilation and all measurements were performed by the same trained examiner. Three images were obtained from each eye to create a mean image, as follows: the examiner traced an ellipse around the scleral limit of the disc and then the program performed the analysis. In accordance with the manual published by the manufacturer, the polarimetric data were obtained from a scanned area of 256 X 256 pixels and each pixel correlated with a value by the software. The software also creates an ellipse that comprises 1.75 diameter of the initial ellipse traced by the examiner and the data obtained in the scanned area are divided into superior, inferior, temporal and nasal quadrants to perform the calculation of the parameters. The parameters used in the current analyses were those shown in the printed

\begin{tabular}{|c|c|c|c|c|}
\hline & \multicolumn{2}{|c|}{$\begin{array}{c}\underset{n=46}{\text { Glaucomatous }} \\
\text { nat }\end{array}$} & \multicolumn{2}{|c|}{$\begin{array}{c}\text { Nonglaucomatous } \\
n=44\end{array}$} \\
\hline & $\underset{n=36}{O O D}$ & $\begin{array}{c}\text { OS } \\
n=34\end{array}$ & $\begin{array}{c}\text { OD } \\
n=42\end{array}$ & $\underset{n=39}{\text { OS }}$ \\
\hline $\begin{array}{l}\text { Absolute glaucoma } \\
\text { or Phthisis }\end{array}$ & 3 & 6 & 0 & 0 \\
\hline Cataracts & 3 & 2 & 1 & 1 \\
\hline $\begin{array}{l}\text { Visual field did not match } \\
\text { the inclusion criteria }\end{array}$ & 0 & 2 & 0 & 0 \\
\hline Fundus venous occlusion & n 2 & 1 & 0 & 0 \\
\hline Previous trabeculectomy & 1 & 1 & 0 & 0 \\
\hline Pseudophakia & 1 & 0 & 1 & 4 \\
\hline Total & 10 & 12 & 2 & 5 \\
\hline
\end{tabular}

result, that are: symmetry, superior ratio, inferior ratio, superior/nasal, maximal modulation, ellipse modulation, average thickness, ellipse average, superior average, inferior average, superior integral, deviation from normal graph ${ }^{(7)}$. The number was not used in this analysis.

\section{Statistical Analysis}

Mann-Whitney's test was used to test the homogeneity of the two groups in regard to age. The Wilcoxon test was used to compare RNFL measurements of right and left eyes in both groups. Mann-Whitney's test was applied in order to compare the obtained values of the parameters of the two groups. The frequency of outside normal parameters and quadrants of the deviation from normal graph, as determined by the software, in both groups was also analyzed by chisquare or Fisher's exact test.

\section{RESULTS}

Almost all parameters included in the result of GDx showed a statistically significant difference between glaucomatous and nonglaucomatous subjects in this study, except the symmetry parameter for left eyes (Table 4).

Table 5 shows that the frequency of parameters outside normal was significantly higher in the glaucomatous group regarding these parameters for both eyes: maximal modulation (for right eyes $30 \%$ of this parameter was shown as outside normal in the glaucomatous group and $9 \%$ in the nonglaucomatous, $35 \%$ and $5 \%$ in the glaucomatous and the nonglaucomatous groups respectively for left eyes), ellipse modulation (19\% and $2 \%$ for right eyes, $12 \%$ and 0 for left eyes), superior average (11\% and 0 for right eyes, $15 \%$ and 0 for left eyes) and inferior average (22\% and 0 for right eyes, $23 \%$ and 0 for left ones).

Table 6 shows that the frequency of quadrants outside normal $(\mathrm{p}<5 \%)$ in the glaucomatous group was significantly higher in the inferior quadrant for both eyes (30\% of the inferior

\begin{tabular}{|c|c|c|c|c|c|c|}
\hline & $\begin{array}{l}\text { GI OD } \\
(n=36)\end{array}$ & $\begin{array}{l}\text { NonGI OD } \\
(n=42)\end{array}$ & $\begin{array}{c}P^{*} \\
(\mathrm{OD})\end{array}$ & $\begin{array}{l}\text { GI OS } \\
(n=34)\end{array}$ & $\begin{array}{c}\text { NonGI OS } \\
(n=39)\end{array}$ & $\begin{array}{c}\mathbf{P}^{*} \\
(\mathrm{OS})\end{array}$ \\
\hline Symmetry & 1.18 & 1.06 & $0.019^{* \star}$ & 1.02 & 1.00 & 1.000 \\
\hline Superior ratio & 1.94 & 2.62 & $0.014^{*}$ & 1.50 & 2.13 & $0.000^{*}$ \\
\hline Inferior ratio & 1.70 & 2.55 & $0.000^{*}$ & 1.51 & 2.12 & $0.000^{*}$ \\
\hline Superior/nasal & 1.54 & 1.91 & $0.000^{*}$ & 1.65 & 2.19 & $0.000^{*}$ \\
\hline Maximal modulation & 1.07 & 1.37 & $0.000^{*}$ & 0.93 & 1.37 & $0.000^{*}$ \\
\hline Ellipse modulation & 1.90 & 2.80 & $0.000^{*}$ & 1.76 & 2.41 & $0.000^{*}$ \\
\hline Average thickness & 64.50 & 68.00 & $0.014^{*}$ & 61.00 & 66.00 & $0.015^{*}$ \\
\hline Ellipse average & 63.00 & 71.50 & $0.000^{*}$ & 60.00 & 70.00 & $0.000^{*}$ \\
\hline Superior average & 68.00 & 80.00 & $0.000^{*}$ & 64.50 & 74.00 & $0.000^{*}$ \\
\hline Inferior average & 63.50 & 83.50 & $0.000^{*}$ & 66.50 & 80.00 & $0.000^{*}$ \\
\hline Superior integral & 0.19 & 0.22 & $0.020^{*}$ & 0.18 & 0.21 & $0.012^{*}$ \\
\hline
\end{tabular}


quadrants were outside normal in the glaucomatous group and $2 \%$ in the nonglaucomatous for right eyes, $20 \%$ in the glaucomatous and $3 \%$ in the nonglaucomatous for left eyes).

Table 7 shows that the values of the parameters differ in a statistically significantly way between right and left eyes in the nonglaucomatous group, except symmetry and superior/nasal. This difference was not detected in the glaucomatous group, except for the superior ratio. The glaucomatous paired eyes were also stratified for initial, moderate and severe glaucomatous visual field loss (MD $\leq-10 \mathrm{~d} \beta, \mathrm{n}=3 ;-10 \mathrm{~d} \beta<\mathrm{MD} \leq-20$ $d \beta, n=4$ e $M D \geq-20 d \leq, n=3$ respectively) and still no difference between the parameters of right and left eyes was observed.
DISCUSSION

It is well documented that racial differences exist in the appearance of the normal optic nerve $\mathrm{e}^{(9,11-13)}$. Using prior versions of polarimeters it was also observed that racial differences are seen in the retardation data from $\mathrm{RNFL}^{(14-15)}$

The GDx software contains a database developed in an American population. The software has the aim to differentiate glaucomatous from normal subjects, but it is based on a specific population.

In urban Americans, Germans and Japanese the retardation data differ between normal and glaucomatous subjects ${ }^{(16-20)}$.

\begin{tabular}{|c|c|c|c|c|c|c|c|c|}
\hline & GI OD & $\%$ & NonGI OD & $\%$ & GI OS & $\%$ & NonGI OS & $\%$ \\
\hline Symmetry & $13^{*}$ & 36 & $3^{*}$ & 7 & 9 & 26 & 6 & 15 \\
\hline Superior ratio & 4 & 11 & 2 & 5 & $17^{\star \star}$ & 50 & $4^{\star \star}$ & 10 \\
\hline Inferior ratio & 6 & 17 & 2 & 5 & $20^{\star *}$ & 59 & $7^{\star \star}$ & 18 \\
\hline Superior/nasal & $20^{*}$ & 55 & $8^{*}$ & 19 & 6 & 18 & 2 & 5 \\
\hline Maximal modulation & $11^{*}$ & 30 & $4^{*}$ & 9 & $12^{\star \star}$ & 35 & $2^{\star \star}$ & 5 \\
\hline Ellipse modulation & $7^{*}$ & 19 & $1^{*}$ & 2 & $4^{\star *}$ & 12 & $0^{* *}$ & 0 \\
\hline Average thickness & 0 & 0 & 0 & 0 & 0 & 0 & 0 & 0 \\
\hline Ellipse average & $3^{*}$ & 8 & $0^{*}$ & 0 & 2 & 6 & 0 & 0 \\
\hline Superior average & $4^{*}$ & 11 & $0^{*}$ & 0 & $5^{\star *}$ & 15 & $0^{\star \star}$ & 0 \\
\hline Inferior average & $8^{*}$ & 22 & $0^{*}$ & 0 & $8^{* *}$ & 23 & $0^{* *}$ & 0 \\
\hline Superior integral & 0 & 0 & 0 & 0 & 3 & 9 & 2 & 5 \\
\hline
\end{tabular}

\begin{tabular}{|c|c|c|c|c|c|c|c|c|}
\hline & GI OD & $\%$ & NonGI OD & $\%$ & GI OS & $\%$ & NonGI OS & $\%$ \\
\hline Superior quadrant & 3 & 8 & 0 & 0 & $8^{* *}$ & 20 & $0^{* \star}$ & 0 \\
\hline Nasal quadrant & 0 & 0 & 0 & 0 & 0 & 0 & 0 & 0 \\
\hline Inferior quadrant & $11^{*}$ & 30 & $1^{*}$ & 2 & $8^{* *}$ & 20 & $1^{* *}$ & 3 \\
\hline Temporal quadrant & 0 & 0 & 0 & 0 & 0 & 0 & 0 & 0 \\
\hline
\end{tabular}

\begin{tabular}{|c|c|c|c|c|c|c|}
\hline & GI OD $(n=23)$ & GI OS $(n=23)$ & $\mathbf{P}$ & NonGI OD $(n=37)$ & NonGI OS $(n=37)$ & $\mathbf{P}$ \\
\hline Symmetry & 1.18 & 1.02 & 0.153 & 1.06 & 1.00 & 0.688 \\
\hline Superior ratio & 1.94 & 1.50 & $0.002^{*}$ & 2.62 & 2.13 & $0.000^{*}$ \\
\hline Inferior ratio & 1.70 & 1.51 & 0.200 & 2.55 & 2.12 & $0.005^{*}$ \\
\hline Superior/nasal & 1.54 & 1.65 & 0.256 & 1.91 & 2.19 & 0.154 \\
\hline Maximal modulation & 1.07 & 0.93 & 0.135 & 1.37 & 1.37 & $0.002^{*}$ \\
\hline Ellipse modulation & 1.90 & 1.76 & 0.649 & 2.80 & 2.41 & $0.006^{*}$ \\
\hline Average thickness & 64.50 & 61.00 & 0.398 & 68.00 & 66.00 & $0.000^{*}$ \\
\hline Ellipse average & 63.00 & 60.00 & 0.869 & 71.50 & 70.00 & $0.000^{*}$ \\
\hline Superior average & 68.00 & 64.50 & 0.554 & 80.00 & 74.00 & $0.003^{*}$ \\
\hline Inferior average & 63.50 & 66.50 & 0.269 & 83.50 & 80.00 & $0.007^{*}$ \\
\hline Superior integral & 0.19 & 0.18 & 0.230 & 0.22 & 0.21 & $0.000^{*}$ \\
\hline
\end{tabular}


Also these differences were previously described in a Brazilian population $^{(21-22)}$. In agreement with those prior studies all parameters calculated based on the polarimetric data obtained by GDx differ between normal and glaucomatous eyes of individuals from the analyzed population, except the symmetry parameter for left eyes.

The fact that symmetry did not differ between glaucomatous and nonglaucomatous subjects was in agreement with other authors' findings ${ }^{(17,22-23)}$. In agreement with our result, it was also observed that all the variables provided by the software differ significantly between eyes of patients with glaucomatous perimetric abnormalities and control subjects, except the "superior/inferior" ratio ${ }^{(24)}$.

In this study the parameters that are more frequently shown as outside normal in both eyes of glaucomatous subjects are maximal modulation, ellipse modulation, superior average and inferior average.

The presence of inferior quadrant in the deviation from normal graph suggests glaucomatous loss. Temporal and nasal quadrants do not seem to play an important role in differentiating glaucomatous from normal subjects in this population. This finding is consistent with the results of a previous study ${ }^{(24)}$. It was also seen that superior and inferior quadrants did correlate with results of psychophysical tests in glaucomatous subjects. This result was not observed in nasal and temporal quadrants ${ }^{(24)}$.

A statistically significant difference between the data obtained from right and left eyes of nonglaucomatous subjects was observed. This difference was not expected to be significant, because it is well known that fellow eyes have some degree of correlation. However this finding is consistent with those previously reported in studies performed with other methods of RNFL analysis ${ }^{(25)}$.

It was also observed that intraindividual differences between the nerve fiber layer are not uncommon, maybe due to nonconnection of some ganglion cells to the respective cerebral nuclei during the early period of life ${ }^{(26)}$.

On the other hand, it was shown that in normal subjects, retardation data obtained with GDx in fellow eyes are highly correlated, but data obtained from some specific NFL regions differ between right and left eyes. The authors attribute these findings to artifacts in the measurements ${ }^{(27)}$.

This is a real possibility because it is well documented that inter- and intraindividual variations in the corneal axis polarization could influence in the RNFL polarization data aquisition by the polarimeter ${ }^{(28,29)}$.

In glaucomatous eyes no differences were observed between the majority of measurements obtained from right and left eyes, probably due to some advanced cases (52,86\% of the glaucomatous eyes had moderate to severe visual field loss), which could have masked some possible existing difference observed in the nonglaucomatosous eyes. On the other hand, the difference was not seen also in the group of paired eyes with initial visual field loss, but we should consider that this sample was limited $(n=3)$. Further studies are necessary to ellucidate if differences between right and left eyes are seen in glaucomatous patients.

\section{CONCLUSIONS}

In conclusion, in a Brazilian population over 40 years the parameters obtained by the GDx differ between normal and glaucomatous eyes and this finding is in agreement with other studies. The presence of some parameters, such as maximal modulation, ellipse modulation, superior average, inferior average or inferior quadrant of the deviation from normal graph, assigned as outside normal, may suggest glaucomatous damage. Some asymmetry between right and left eyes in normal subjects was observed by the GDx results. These asymmetries, in our opinion, were probably due to artifact and should be considered when using this instrument for developing scientific clinical studies, in order to avoid creating unintentional bias.

\section{ACKNOWLEDGEMENTS}

To Dr. Rohit Varma, from the Doheny Eye Institute, Los Angeles, CA, for his help in revising the manuscript.

To Dr. Hanna A. Rothschild, medical editor, for her help in revising the text.

\section{RESUMO}

Objetivos: Comparar os resultados da polarimetria de varredura a laser da camada de fibras nervosas obtidas por meio do GDx Scanning Laser System ${ }^{\circledR}$ em brasileiros portadores de glaucoma primário de ângulo aberto e indivíduos não glaucomatosos acima de 40 anos, analisando também as diferenças obtidas entre olhos direitos e esquerdos. Métodos: Foram incluídos neste estudo 46 pacientes portadores de glaucoma primário de ângulo aberto e 44 pacientes normais. Os dados de retardo polarimétrico foram obtidos por meio do GDx Scanning Laser System ${ }^{\circledR}$. As medianas dos parâmetros impressos no resultado foram comparadas nesses dois grupos, separadamente para olhos direitos e esquerdos, usando o teste de Mann-Whitney. A freqüência de parâmetros impressa como fora da normalidade e quadrantes estatisticamente alterados do gráfico "deviation from normal" foram comparados nesses dois grupos usando chi-quadrado e o teste exato de Fischer. Resultados: Todos os parâmetros obtidos pelo GDx diferiram de maneira estatisticamente significante entre esses dois grupos, exceto simetria nos olhos esquerdos. A freqüência do quadrante inferior com $\mathrm{p}<5 \%$ no gráfico "deviation from normal" foi maior no grupo glaucomatoso. Os parâmetros mais freqüentemente registrados como fora da normalidade no grupo glaucomatoso foram: modulação máxima, modulação da elipse, média superior e média inferior. Todos os parâmetros 
exceto simetria e nasal/superior diferiram entre olhos direitos e esquerdos no grupo de indivíduos não glaucomatosos. Conclusão: Os parâmetros obtidos pelo GDx diferiram entre glaucomatosos e normais desta população. Alguns parâmetros desviaram da normalidade com maior freqüência no grupo de glaucomatosos. Foi observada diferença evidente entre olhos direitos e esquerdos de indivíduos não glaucomatosos nesse grupo.

Descritores: Glaucoma; Fibras Nervosas; Retina/patologia, Técnicas de diagnóstico oftalmológico, Perimetria

\section{REFERENCES}

1. Hoyt WF, Friesén L, Newman NM. Fundoscopy of nerve fiber layer defects in glaucoma. Invest Ophthalmol 1973;12:814-29.

2. Quigley HA, Dunkelberger GR, Green WR. Retinal ganglion cell atrophy correlated with automated perimetry in human eyes with glaucoma. Am J Ophthalmol 1989;107:453-64.

3. Sommer A, Katz J, Quigley HA, Miller NR, Robin AL, Richter RC, et al. Clinically detectable nerve fiber atrophy precedes the onset of glaucomatous field loss. Arch Ophthalmol 1991;109:77-83.

4. Sommer A. Retinal nerve fiber layer [commented on Am J Ophthalmol 1995; 120:577-86]. Am J Ophthalmol 1995;120:665-67.

5. Dreher AW, Reiter K. Retinal laser ellipsometry: a new method for measuring the nerve fiber layer thickness distribution. Clin Vis Sci 1992;7:481-6.

6. Weinreb RN, Dreher AW, Coleman A, Quigley HA, Shaw B, Reiter K. Histopathologic validation of Forrier-ellipsometry measurements of retinal nerve fiber layer thickness. Arch Ophthalmol 1990;108:557-60.

7. Laser diagnostic technologies. San Diego, CA - Addendum to the NFA System Manual: Part I - The GDX Glaucoma Scanning System - Nerve Fiber Layer Analyser, NFA ${ }^{\text {TM }}$ System Manual, 1996, 99p.

8. Weinreb RN, Zangwill LM, Berry CA, Bathija R, Sample PA. Detection of glaucoma with scanning laser polarimetry. Arch Ophthalmol 1998;116:1583-9.

9. Beck RW, Messner DK, Musch CD, Martonyi CL, Lichter PR. Is there racial difference in physiologic cup size? Ophthalmology 1985;92:873-6.

10. Alvarenga LS, Moura CR, Mello PA, Prata Jr JA. Equivalente esférico e valores da espessura da camada obtidas com o GDX Scanning Laser System ${ }^{\circledR}$. Arq Bras Oftalmol 1999;62:693-5.

11. Quigley HA, Brown AE, Morrison JP, Drance SM. The size and shape of the optic disk in normal human eyes. Arch Ophthalmol 1990;108:51-7.

12. Varma R, Tielsch JM, Quigley HA, Hilton SC, Katz J, Spaeth G, et al. A Race-, age-, gender-, and refractive error-related differences in the normal optic disc. Arch Ophthalmol 1994;112:1068-76.

13. Xu L, Chen P, Chen YY, Takahashi Y, Wang L, Milles R. Quantitative nerve fiber layer measurements using scanning laser polarimetry and modulations parameters in detection of glaucoma. J Glaucoma 1998;7:270-7.
14. Poinoosawmy D, Fontana L, Wu JX, Fitzke FW, Hitchings RA. Variations of nerve fiber layer thickness measurements with age and ethnicity by scanning laser polarimetry [commented on Br J Ophthalmol 1997;81:338-9]. Br J Ophthalmol 1997;81:350-4

15. Tjon-Fo-Sang MJ, Lemij HG. Retinal nerve fiber layer measurements in normal and black subjects as determined with scanning laser polarimetry. Ophthalmology 1998;105:78-81.

16. Funaki S, Shirakashi M, Yaoeda K, Abe H, Kunimatsu S, Suzuki Y, et al. Specificity and sensitivity of glaucoma detection in the Japanese population using scanning laser polarimetry. Br J Ophthalmol 2002;86:70-4.

17. Nguyen NX, Horn FK, Hayler J, Wakili N, Junemann A, Mardin CY. Retinal nerve fiber layer measurements using laser scanning polarimetry in different stages of glaucomatous optic nerve damage. Graefes Arch Clin Exp Ophthalmol 2002;240:608-14.

18. Choplin NT, Lundy DC, Dreher AW. Differentiating patients with glaucoma from glaucoma suspects and normal subjects by scanning laser polarimetry. Ophthalmology 1998;105:2068-76.

19. Horn FK, Jonas J, Martus P, Mardin CY, Budde WM. Polarimetric Measurement of retinal nerve fiber ayer thickness in glaucoma diagnosis. J Glaucoma 1999;8:353-62.

20. Weinreb RN, Shakiba S, Zangwill LM. Scanning laser polarimetry to measure the nerve fiber layer of normal and glaucomatous eyes. Am J Ophthalmol 1995;119:627-36.

21. Suzanna Jr R, Takahashi WY, Nakamura NFK. Sensibilidade e especificidade da avaliação da camada de fibras nervosas examinadas através da polarimetria de varredura a laser. Rev Bras Oftalmol 1998;57:17-21.

22. Medeiros FA, Susanna-Junior R. Análise de Fourrier das medidas de espessura da camada de fibras nervosas da retina obtidas com a polarimetria a laser. Rev Bras Oftalmol 2002;61:475-84.

23. Paczka JA, Friedmann DS, Quigley HA, Barron Y, Vitale S. Diagnostic capabilities of frequency-doubling technology, scanning laser polarimetry, and nerve fiber layer photographs to distinguish glaucomatous damage. Am J Ophthalmol 2001;131:188-97.

24. Horn FK, Mardin CY, Jonas J, Korth M. Association between sensory tests and nerve fiber layer analysis with the GDx [abstract]. Invest Ophthalmol Vis Sci 1998;39:S703.

25. Schuman JS, Hee MR, Puliafito CA, Wong C, Pedut-Kloitzman T, Lin CP, et al. Quantification of nerve fiber layer thickness in normal and glaucomatous eyes using optical coherence tomography. Arch Ophthalmol 1995;113:586-96.

26. Tjon-Fo-Sang MJ, Vries J, Lemij HG. Measurements by nerve fiber layer thickness in normal subjects and patients with ocular hypertension. Am J Ophthalmol 1996;122:220-7.

27. Essock EA, Sinai MJ, Fechtner RD. Interocular symmetry in nerve fiber layer thickness of normal eyes as determined by polarimetry. J Glaucoma 1999;8:90-8.

28. Greenfield DS, Knighton RW, Huang XR. Effect of corneal polarization axis on assessment of retinal nerve fiber layer thickness by scanning laser polarimetry [commented on Am J Ophthalmol 2001;131;528-9]. Am J Ophthalmol 2000;129:715-22.

29. Greenfield DS, Knighton RW. Stability of corneal polarization axis measurements for scanning laser polarimetry. Ophthalmology 2001;108:1065-9.

\section{Ao enviar unn antigjo panra publicação,

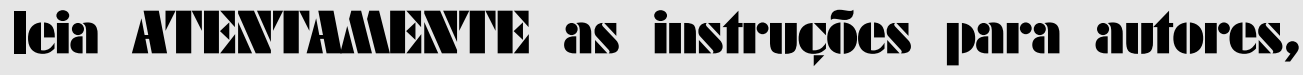 constante mo final de cada fanscículo.}

